\title{
Klassikkoa lukiessa
}

\section{Darwin on ilmestynyt uudelleen suomeksi.}

On luonnollista käyttää adjektiivia 'klassinen' vanhoista taideteoksista; käynti Delfoin temppelien raunioilla, Firenzen keskusaukioilla tai Turun tuomiokirkossa karistaa kaikki tätä koskevat epäilykset. Luontevalta ja totunnaiselta nimitys vaikuttaa myös sovellettuna filosofisiin tai yhteiskuntatieteellisiin teoksiin; Platonin dialogeja tullaan varmasti lukemaan kautta maailman sivun, ja Marxin - tai Weberin - teosten elävä merkitys tuntuu itsestään selvältä. Mutta voidaanko luonnontieteellisiin teoksiin soveltaa nimitystä 'klassikko' tarkoittaen tällä, että teokset ovat elävää nykyisyyttä eivätkä vain osa historiaa?

Vastaus on kategorisesti kyllä. Kovin lattea kuva luonnontieteistä on sillä, joka muuta väittää. Perusteluna pitäisi kai olla jotakin sellaista, että luonnontiede etenee siirtämällä yksinkertaisesti ja suoraviivaisesti syrjään luonnon ilmiöitä peittävää salaperäisyyden verhoa: kun jokin asia on keksitty, niin se on keksitty, eikä siitä sen enempää. Totuus on kuitenkin toinen. Toki luonnontieteen ideana on oikean tiedon hankkiminen luonnon ilmiöistä, mutta tämä on mutkitteleva, vaikea ja vahvasti historiallinen (ja jännittävä) prosessi.

Myöntävää vastaustani täytyy ehkä perustella. Asian ydin on siinä, että luonnontieteellinen tiedostus on sidottu kunkin aikakauden vallitsevaan ajattelutapaan. Siten jokainen merkittävä tieteellinen keksintö merkitsee myös murrosta ajattelussa, tunnettujen tosiasioiden asettamista uuteen järjestykseen, ehkäpä koko maailmankuvan muuttumista (darwinistiseen evoluutioteoriaan tämä luonnehdinta sopii jos mihin). Uuden tosiasia-aineiston kertyminen, 'löydöt' kapeassa mielessä, on vain prosessin yksi osa, olennaisempi osa on ajatuksellinen, teoreettinen murros.

Jälkikäteen voimme vain koettaa rekonstruoida, mitä suurten tieteellisten murrosten synnyttäminen todella on edellyttänyt. Historia on viekasta: tämän hetken vallitsevat ajattelutavat tieteissä (jos muuallakin) vaikuttavat niin itsestään selviltä, että tuntuu vaikealta vakavasti kuvitella niille vaihtoehtoja, menneessä sen paremmin kuin tulevassakaan. Mutta voimme olla varmoja, että jokaisen menneiden aikojen merkittävän tiedemiehen ajattelun voima antaa pysyvää tukea saman alan ongelmien parissa kamppaileville; esimerkiksi Darwinista on todettu, että hän kävi monikymmenvuotisen tutkijantyönsä aikana evoluutioteorian ongelmia ja teoriaan mahdollisesti kohdistuvia vastaväitteitä läpi johdonmukaisemmin kuin kukaan muu on tehnyt ja todennäköisesti tulee tekemäänkään. Niinpä: kun pitelemme kädessämme teosta, jossa jonkin luonnontieteen ajatuksellinen murros on perusteltu ja kiteytetty - sellaisia teoksia on, Darwinin 'Lajien synty' ei ole ainoa - pitelemme kädessämme klassikkoa.

Darwin siis kuuluu klassikkojemme (ja klassikkoklubimme) katraaseen mutta Darwinilla oli myös oma klassinen eläintarhansa. 15. 9. 1835 hän kirjoitti muistikirjaansa: "This archipelago consists of ten principal islands, 
of which five exceed the others in size." Puhe oli Galapagos-saarista, Darwinin peippojen asuinpaikasta, joille Her Majesty's Ship Beagle oli juuri saapunut Darwin mukanaan ja joiden erikoislaatuinen eläimistö oli eräs darwinistisen kehitysopin vauhdittaja. Täytyy ehkä olla luonnon harrastaja, jotta voisi todella arvostaa sitä valtavaa luonnontuntijan ammattitaitoa, jota Darwin osoittaa Beagle'n maailmanympärimatkalla tekemissään muistiinpanoissa. Etenkin kun pelkkä havainnointi ja tarkkuus ei ollut kyllin, oli löydettävä moninaisuuden ykseys, tehtävä synteesi. Siitä kertoo 'Lajien synty'.

Rikas tulkintakirjallisuus kukkii Darwinin perinnöllä, sekin klassikon tuntomerkkejä. Eräs mielenkiintoinen ulottuvuus iskee nykypäivän tieteenfilosofisen keskustelun ytimeen. Darwin eli John Stuart Millin ja William Whewellin aikalaisena ja kirjoitti tutkimuksensa aikansa tieteenfilosofiaa tiiviisti seuraten. Hänen tieteellinen metodinsa oli täysin tietoinen ja hyvin mielenkiintoinen; siitä on viime vuosina päästy selvyyteen. Läheskään kaikkea arvokasta tästä teemasta ei vielä ole ammennettu.

On siis tapaus, että Darwin on ilmestynyt uudelleen suomeksi-vaikkakin lyhennettynä laitoksena. Kaikki kunnia lyhennelmän toimittaneelle Richard E. Leakeylle tutkijana ja evoluutikkona, mutta pelkäänpä, että lyhennelmä jää alamittaiseksi. Klassisen teoksen merkitys ei lopultakaan ole sen pelkistetyssä sanomassa - tämän voi välittää oppikirjana tai opintopiirioppaana. Merkitys on kokonaisuudessa, koko päättelyketjussa ja argumentaatiossa viimeisine vivahteineen; taitavinkin lyhennelmä tekee niille väkivaltaa. Klassikko on johtanut ajattelutavan murrokseen omana aikanaan - vain tuntemalla teoksen kokonaan, suhteessa omaan aikaansa, oivallamme sen merkityksen tänään (tässäkin historian viekkautta).

Joutua lukemaan Darwinia lyhennettynä on sitä paitsi sinänsä onnettomuus; hänen tyylilleen ja kielelleen on vaikea löytää rinnasteita, ellei joku Lucretius. Toistakaamme 'Lajien synnyn' viimeisen kappaleen ensimmäinen sekä viimeinen virke:

"It is interesting to contemplate a tangled bank, clothed with many plants of many kinds, with birds singing on the bushes, with various insects flitting about, and with worms crawling through the damp earth, and to reflect that these elaborately constructed forms, so different from each other, and dependent on each other in so complex a manner, have all been produced by laws acting around us . . . There is grandeur in this view of life, with its several powers, having been originally breathed by the Creator into a few forms or into one; and that, whilst this planet has gone cycling on according to the fixed law of gravity, from so simple a beginning endless forms most beautiful and most wonderful have been, and are being evolved."

Versokoot tuhannet tulkinnat, Darwin puhuu itse puolestaan. 